\title{
Analysis of Factors Affecting the Payment of Zakat in Special Capital Region (DKI) of Jakarta
}

\author{
Dwi Poetra Sedjati ${ }^{1}$, Yuzwar Z. Basri ${ }^{1}$ \& Uswatun Hasanah ${ }^{1}$
}

${ }^{1}$ Trisakti University, Jakarta, Indonesia
Correspondence: Dwi Poetra Sedjati, Trisakti University, Jakarta, Indonesia, E-mail: willy.arafah@ @otmail.com

Received: January 8, 2018

Accepted: January 12, 2018

Online Published: February 19, 2018

\begin{abstract}
The objective of this research is for analyzing and describing matters that affect the willingness of the community in the DKI Jakarta in paying the zakat. This is done through a theoretical model of knowledge, attitude, religiousness, motivation, and income of the Muslim community in their payment of the zakat. This model will specifically empirically test the direct effects of knowledge, attitude, motivation, religiousness, and income of the Islamic community to the impacts of the willingness of the Islamic community in paying the zakat. This research is conducted by taking a total of 430 Islam community members as research objects in 5 region of DKI Jakarta, by using the purposeful sampling technique. The total of respondents as the research population is 430 persons. For interpreting and analyzing the data, the analytical technique used is the Structural Equation Model (SEM) using the AMOS software. The result of the hypothesis testing has verified that the factors of knowledge, attitude, religiousness, motivation, and income of the Muslim community have significantly increased their willingness to pay the zakat. Also the model used in this research is acceptable and is valid, as indiccated by the appropriateness index, all of which have met the requirements. The results of this study indicate that there is the potential for increasing the zakat revenue through increasing the willingnes/interest of the muzakki to pay the zakat, as such increased interest is affected by the increasing knowledge, attitude, religiousness, motivation, and income of the muzakki. This has increased the conviction that the zakat has a very strategic function in the economy of the state, namely as one of the instruments for distributing wealth and increase the wellbeing of society as a whole.
\end{abstract}

Keywords: 6 variables, knowledge, attitude, religuiousness, motivation, income, interest, zakat.

\section{Introduction}

The syariah economy has continued to grow and develop in Indonesia. This is indicated by the increasing public awareness of the need for carrying out economic activities that are line line with the syariah norms. Aside from the success story of the syariah banking and finance, there are also various criticisms, namely that the syariah economy should not be confined to the banking and finance industry. There are still many other syariah economic aspects, such as the syariah based business activities, the islamic consumption behaviour, including the islamic philatropic behaviour. One of the rules in Islam that are related to social relations is the zakat. The concern of Islam to handle the problem of the poor, and to avert that wealth should not circulate only among the rich, is also to enhance the sense of brotherhood between the haves and non-haves, by nurturing the religious spirit by expressing these concerns in economic terms (Al Munawar, 1997). Islam with its muslim vision and syariah paradigm has the role of a khalifatullah fil Ardhi, intrinsically abhors unemployment and poverty. If the problem of unemployent cannot be resolved then it will have adverse repercussions for human the individual and for the community in general. Allah SWT has made the human being as the khalifah on earth, and Allah SWT has also provided everything on earth for being managed for meeting all of their needs (Qardhawi, 2005). Zakat is one of the mandatory obligations for the muslim people. In addition for the cleansing of wealth, zakat 
also has a social function, as can be seen from the distribution of the zakat, encompassing eight groups of the asnaf samaniyah), namely the poor (fakir miskin), amil, muallaf riqab, gorim, fisabilillah and the ibnu sabil. These eight goups, is on a syara basis, people who are entitled to receive the zakat. This is one of the ways of Islam to eradicate poverty (Yafie, 1994). Zakat is the manifestation of social concern, which averts or at least reduces the excessive accumulation or conglomoration and the circulation of wealth only among the rich.Among others by reducing the gap between those with excessive wealth and those with deficient wealth.Therefore it is very important to distribute economic empowerment of the poor in order to attain an Indonesian nation that is sovereign, prosperous and that has a noble character through the enhancement of social consciousness, that averts or at least prevents the excessive or conglomoration of wealth only among the rich. One way is by reducing the gap between the have and the have-nots of wealth/assets In that respect it it necessary, through zakat, to economically empower the poor people in order that the Indonesian nation could become souvereign and prosperous and have a noble character. In that context, the role of the distribution of the zakat is a determining aspect. This implies the importance of the Islamic law as part of the national law, considering that $87.21 \%$ of the total population are muslims. As such, each policy of the government must have a direct impact on the muslim community of Indonesia. Conseqently, law Number 38 of 1999 on the Zakat management has been ratified by President Habibie (Zulfahmi, 2007). The ulamas have agreed that any muslim who has excess wealth has the obligation to give the zakat through channels that have been set by Allah SWT. According to Yusuf al-Qardawi, the importance of the zakat in Islam is closely intertwined with two dimensions, namely the ubudiyah and the ijtima'iyyah waiqtishadiyyahi (social economy) dimensions. The dimension of the ubudiyah can be found in 82 ayats, in which Allah SWT explains zakat as always in conjunction with the shalat in the AlQuran. For this reason Yusuf al-Qardhawi stated that the shalat is the pillar of the religion and that zakat is the lighthouse of the religion (Qardhawi, 2009). In Islam the wealth of a person contains the right of Allah SWT. This right is known as the zakat. Zakat refers to the wealth/asset that must be spent upon having met the conditions as set by religion and channeled to people who also have already been determined. Zakat is a form of a unique ibadah. In addition of having a vertical dimension, namely the relation to Allah (hablun minallah), the zakat also has the horizontal dimension (hablun minannas), for alleviating the burdens of the destitute. Allah SWT has warned that we must not neglect the wealth/assets that Allah has given. As one of the rukun Islam, the zakat is fardlu'ain. In the Al-Quran the zakat obligation is equally important as the shalat obligation. However, in reality this third rukun Islam has not yet been practiced the way it must be.

The issues that have arisen pertaining to the practice of zakat are among others : first, expansion of the scope of wealth that are subject to the zakat; second, the professionality of its management; third, its just distribution. Other issues that have arisen are: the low trust of the people towards the zakat institution; the low understanding of the public on the zakat; and what incomes must be subject to the zakat (so far only the zakat fitrah is known); the lack of transparency of the zakat managers; the not yet intensive socialization (publications of information); the double-tax issue; and the economic condition that is not yet stable (Qardhawi, 2001). The Islam community is still reluctant to give the zakat, infaq, and sedekah, due to among others they have not yet feel its benefits. They only see the receivers (musttahiq) who directly feel the benefits of the zakat (Saefuddin, 2008). For muslims, zakat is one of the rukun Islam that must be implemented. They recognize that the zakat is mandatory sedekah that as a pillar of Islam must be practiced. A muslim who neglects the zakat is regarded to be deficient in his/her muslim obligations, so that a muslim must be charitable person. A person who claims himself as muslim but is stingy is being questioned about his faith to Allah SWT. Stinginess in this respect is defined as neglecting the zakat. In this context the zakat is concerned about social welfare or the welfare of others. Therefore, Islam deems the payment of zakat as having an economic value in terms of social welfare. For a muslim, zakat is not solely a manifestation of his/her care for the poor, but is regarded as having a very strategic function in the economic system, namely as the instrument for distributing wealth. An exemplification of zakat being an instrument for distrubuting wealth is during the governance of the Islamic khalifah period. AlQardhawi said that in the 10 years era of Khalifah Umar bin Khatab various regions (provinces) had applied the Islamic laws, wherein the muslim people had benefited a period of prosperity. This was vindicated by the absence of not one poor person who was entitled to the zakat. Likewise during the governance of Khalifah Umar bin Abdul Aziz. In his book of Sirah Umar bin Abdul Aziz, Ibnu Abdil Hakam revealed that all of the people were at that time living in prosperity (Qardhawi, 1993). Currently, the zakat has not yet been able to empower the community, not to mention its still inability to enhance prosperity of society, This is in spite of the 
tremendous potential of the zakat in Indonesia. The reserach results of he Center for the Study of Religion and Culture (CSRC) of the UIN Syarif Hidayatullah Jakarta in conjunction with the Ford Foundation, show that the total amount ZIS funds is around 19.3 trillion rupiah per year, of which Rp 5.1 trillion is in the form of goods, and $\mathrm{Rp} 14.2$ trillion in the form of cash. Out of such big funds, one-third ( $\mathrm{Rp} 6.2$ trillion) originate from zakat fitrah, with the remaing of Rp 13.1 trillion originating from wealth zakat (Abubakar, Irfan \& Chaider S, 2006). The potential of the zakat in Indonesia, by using simple calculation is very high as exemplified by the available macro estimates. The estimate could be done from the total number of the work force in Indonesia. If the proportion of mulims in the work force is $87 \%$ of the total number of the work force of 111.97 million, , then the total number of muslins in the work force is 97.4 million persons. The report of the IMZ (Indonesian Magnificence of Zakat) study, in 2011 there are 23,676.263 muzakkis in Indonesia, with the cumulative total in West Java is 4,721.101 persons, in Est Java is 2,871.741 persons, in DKI Jakarta is 2,467.677 persons, in Central Java is 2,181.139 persons, in Banten is $1,324.908$ persons, and in North Sumatra is 1,094,889 persons. The major portion $(60.6 \%)$ of the muzakkiare males, even though one cannot idsregard the potential of female muzakkis (39.4\%). It should also be noted that the majority of the muzakkis are in the 25-59 years age bracket (26.1\% are in the $25-34$ years bracket, $25 \%$ in the $35-44$ bracket, and $26 \%$ are in the $45-59$ bracket (IMZ, 2011:9). To facilitate the discussion of the reearch result, it is necessary to define the problem. The problem formulation is as follows:

- What is the effect of knowledge of the Islamic community in DKI Jakarta on the willingness to pay the zakat?

- What is the effect of attitude of the Islamic community in DKI Jakarta on the willingness to pay the zakat?

- What is the effect of the religiousness of the Islamic community in DKI Jakarta on the willingness to pay the zakat?

- What is the effect of the motivation of the Islamic community in DKI Jakarta on the willingness to pay the zakat?

- What is the effect of income of the Islamic community in DKI Jakarta on the motivation to pay the zakat?

- What is the effect of income of the Islamic community in DKI Jakarta on the willingness to pay the zakat?

- Generally, the objective of this study/research is to decribe matters that affect the motivation/willingness of the community in DKI Jakarta to pay the zakat. Specifically, this study is aimed at revealing :

- For analyzing the effect of the knowledge of the Islamic community in DKI Jakarta on the willingness to pay the zakat.

- For analyzing the effect of attitude of the Islamic community in DKI Jakarta on the willingness to pay the zakat.

- For analyzing the effect of the religiousness of the Islamic community in DKI Jakarta on the willingness to pay the zakat.

- For analyzing the effect of motivation of the Islamic community in DKI Jakarta on the willingness to pay the zakat.

- For analyzing the effect of income of the Islamic community in DKI Jakarta on the motivation to pay the zakat.

- For analyzing the effect of income of the Islamic community in DKI Jakarta on the willingness to pay the zakat.

2. Literature Review

The command for obligating payment of the zakat was acquired in Medinah on the month of Syawal of the second year of the hijrah of Rasulullah SAW. The obligation occurs after the obligation of the Ramadhan fasting and the zakat fitrah. The zakat begun to be obligated in Medinah because the Islamic community had started to be formed, and the obligation was meant to direct the Muslim community, namely as verification of their social solidarity, in the sense that the rich people who pay the zakat are eligible to become muslims. When the muslim community were still in Makkah, Allah SWT had already stated in the Al-Qur'an the payment of wealth that was not yet called zakat but is the obligation to pay the infaq, namely to those who have excess wealth are obligated to those in need, with the amount depending on what they are willing to pay, naturally such willingness being subject to the degree of their faith (Muhammad, 2002). Kanji, et all (2011) have tested the effect of worship, knowledge, of zakat, wealth or income, role of the ulama, credibility of the institution of amil 
zakat and the role of the government, that have partially effected the motivation to pay the zakat. The testing results have shown that the factors of worship (ibadah), zakat knowledge, wealth or income, role of ulamas, credibility of the amil zakat institution have a positive partial effect and significantly affected the motivation to pay the zakat, while the role of the government has no positive and significant effect to the motivation to pay the zakat. Rouf (2011) has tested the effect of faith, religiousness, and income to the willingness of the community to pay the zakat. The results show that faith, religiousness, and income significantly affect the willingness of the community to pay the zakat. Mus'ab (2011) has tested the effect of religiousness, income level, and service to the willingness/motivation of the muzzaki to pay the zakat. Results of the tests show that religiousness, income level, and service have affected the motivation of the muzakki to pay the zakat maal. Huda, Rini, Mardhoni and Putra (2012), in their research of various zakat issues was aimed at finding out the effect of attitude, subjective norms, and control of behaviour to the motivation of the muzakki to pay the zakat. This research had involved 247 muzakkis responding to 300 questionnaires. By using a double linear regression method for the analysis of data, the research found that attitude and behaviour as control variables, have a significant positive to the variable of motivation of the muzakki, whereas the subjective has no effect. The variables of attitude, subjective norms and behaviour controll have respectively the weight of $4.62 \%, 2.88 \%$, and $8.5 \%$ to the motivation variable of the muzakki. The total contribution weight of attitude, subjective norm and the controll variable of behaviour for the muzakki is $16 \%$. This indicates that $84 \%$ of the motivation of the muzakki to pay the zakat is affected by other variables that are not analyzed in this research. Effect of the zakat to income is one of the issues that have emerged among the syariah scholars, with various opinions among them on the matter (Abu Bakar and Abdul Rashid, 2010). The objective of the paper is to identify factors that can affect the Muslim behaviour to the zakat to income. Academicians from three faculties at the International Islamic University Malaysia (IIUM) were used as sample in this study. They were sent questionnares that they themselves have developed that require them to show their level of agreement on certain factors that can affect them in the payment of the zakat to their income. On the basis of the average ranks in payment of zakat, the findings show that social, religious, and economic factor that dominate other relatively egotistical factors. In the majority of the Malaysian states, the collection of the zakat is the third largest after the zakat to work income and zakat to business. Nevertheless, the zakat collection, including zakat at savings, is still not yet satisfactory (Azman and Bidin, 2015). Previous empirical evidence have reported that there are many factors that affect the individual in the paymet of the zakat. This study is aimed at finding out the variables that affect the individual in payment of the zakat at savings, namely the relation between the variables of attitude, reference group, religiousness and credibility of the company that are felt and the compliance to zakat at the savings. The data is analyzed by using the double regression analysis. The data are collected from 80 muslim employees who are employed at the Universitas Utara Malaysia. The findings show that all variables have significant effects to the compliance to zakat at the savings.

\section{Research Methodology}

Research designs are distinguished on the basis of the nature of the scientific exploration, nature of explanation, and method of scientific finding (Ferdinand, 2011). Research design on the basis of the nature of scientific exploration is directed at exploring and developing parts of certain sciences that are expected can contribute to the body of knowledge. This research design can be in the form of basic research and applied research. Population refers to the area of generalization that have certain quality and characteristics that have been applied before. On the basis of such quality and characteristics, the population can be understood as an individual groupor as an observation object that at least has one same characteristic (Cooper \& Emory, 1996). Population in this research is the muslim community in DKI Jakarta, in 5 (five) regions, namely the municipalities of West Jakarta, East Jakarta, North Jakarta, South Jakarta, and Central Jakarta.

\section{Result and Discussion}

The whole model testing is conducted by using analysis of the Structural Equation Model (SEM), that is also used for analyzing the proposed hypothesis. After analyzing the validity of the indicators that form latent variables that have been tested by the confirmatory factor analysis, then the next step is analyzing the Structural Equation Model (SEM) as the full model. Analysis of results of the data processing at the SEM full model stage is conducted by carrying out the fitness test and the statistical test. Results of the data processing for analysis of the full model of the SEM are presented in the following diagram. 


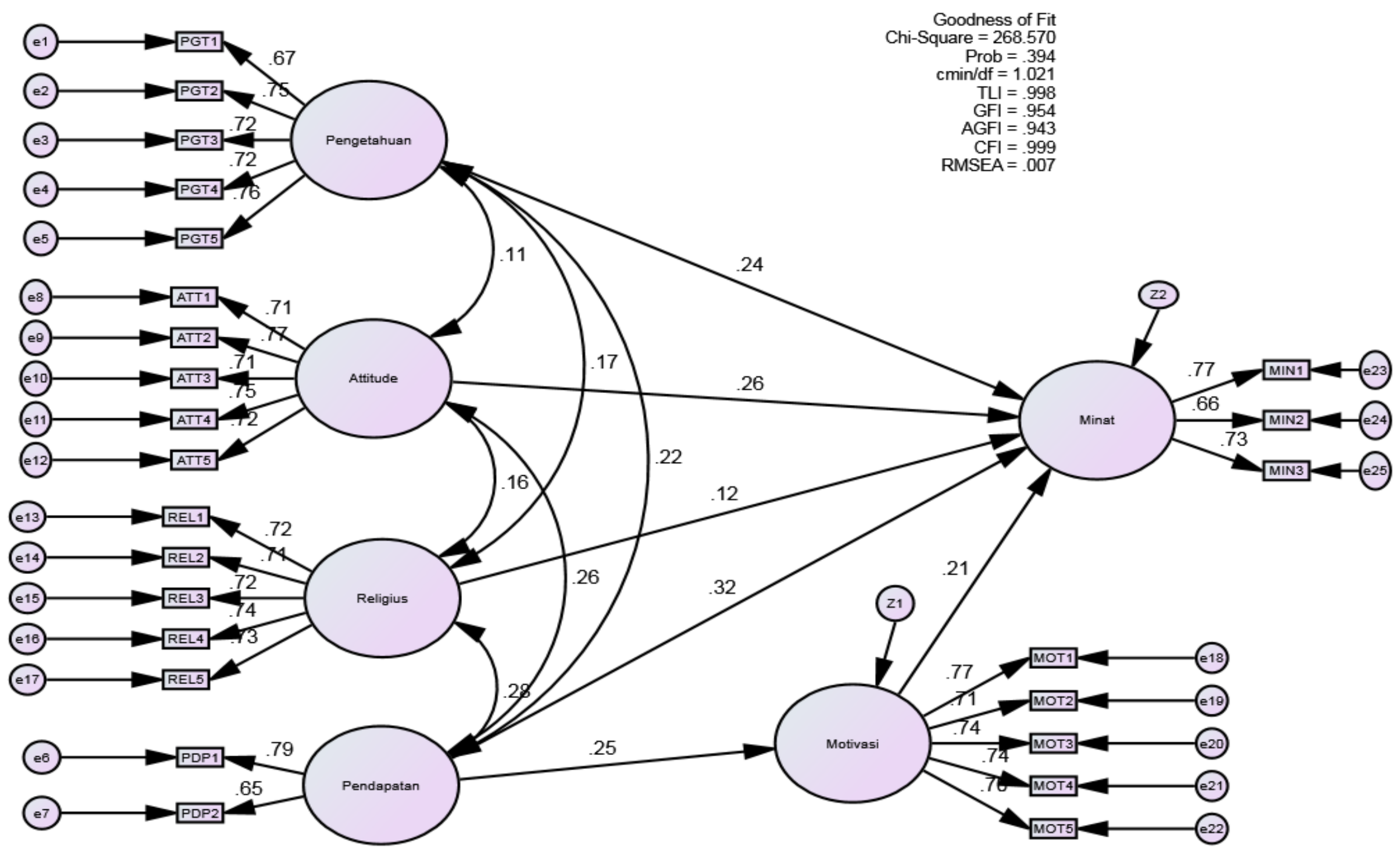

Diagram 1. Results of data processing for analysis of the SEM Full Model 
Testing of the SEM model is aimed at seeing the fit of the model. The testing to the goodness of fit of this full model is conducted by the same method as in the testing of the confirmatory factor analysis (CFA) in testing the goodness of fit of thye model for estimating exogeneous and endogeneous variables. Testing of the hypothesis of he model shows that this model fits the data used in the study, as shown in the following table:

Table 1: Results of Suitability of the Structural Equation Model (SEM)

\begin{tabular}{lccc}
\hline $\begin{array}{c}\text { Goodness of Fit } \\
\text { Index }\end{array}$ & Cut Off Value & $\begin{array}{c}\text { Results of the } \\
\text { Analysis }\end{array}$ & $\begin{array}{c}\text { Evaluation of } \\
\text { the Model }\end{array}$ \\
\hline Chi Square & $\begin{array}{c}479,347 \\
(5 \%, 430)\end{array}$ & Good \\
\hline Probability & $\geq 0,05$ & 0,394 & Good \\
\hline RMSEA & $\leq 0,08$ & 0,007 & Good \\
\hline GFI & $\geq 0,90$ & 0,954 & Good \\
\hline AGFI & $\geq 0,90$ & 0,943 & Good \\
\hline TLI & $\geq 0,95$ & 0,998 & Good \\
\hline CFI & $\geq 0,95$ & 0,999 & Good
\end{tabular}

Source: The primary data is processed in 2016

Results of the data processing analysis show that all construct used for forming the model of the study in the process of analyzing the full SEM model have met the good of fit criteria. The probability value of this analysis is less than the level of significance of 0.394 namely 0.05 greater, indicating that the null hypothesis stating that there is a difference between the population covariance matrix and the population covariance matrix being estimated is rejected. This implies that there is a difference between the population covariance matrix and the population covaraince being estimated and thereby this model cannot be accepted. Other indices on appropriateness of the model, such as GFI $(0,954)$, AGFI $(0,943)$, TLI $(0,998)$, CFI $(0,999)$, RMSEA $(0,007)$ provide sufficient confirmation for accepting the undimensionality of the hypothesis that the above indicators can reflect the latent variables being analyzed.

Results of the testing of the multivariate normality yields a critical value of 6.937 which is greater than the border value of \pm 2.58 , in other words it is greater that the set level of significance. Thereby, the used research data has met the normality of data requirement. In other words, the data in this study has been normaly distributed. The hypothesis testing is conducted on the basis of results of the data processing in the study by using the SEM analysis. Generally, this hypothesis testing is conducted by analyzing the value of the critical ratio $(\mathrm{CR})$ and the value of the probability $(\mathrm{P})$ as results of the data processing compared with the required statistical definitions. The value of the required critical ratio is greater than 1,96 and the value of the required probability is less than 0.005 . If results of the data processing meet such requirements, then the proposed hypothesis in the study is declared acceptable.

The hypothesis testing in this research will discuss in detail and in stages in accordance with the stages of the proposed hypothesis. The last section will discuss the general conclusions to the problem and scope of the study and the significance of the hypothesis on the basis of the available statistical data. This study proposes five hypotheses, and the full discussion is presented below:

Table 2: Hypothesis Testing

\begin{tabular}{lllrrrrr}
\hline & & Estimate & S.E. & C.R. & P & Label \\
\hline Motivation & $<---$ & Income & .295 & .075 & 3.949 & $* * *$ & \\
\hline Willingness & $<---$ & Motivation & .208 & .054 & 3.834 & $* * *$ & \\
\hline Willingness & $<---$ & Knowledge & .242 & .053 & 4.535 & $* * *$ & \\
\hline Willingness & $<---$ & Attitude & .269 & .056 & 4.803 & $* * *$ & \\
\hline Willingness & $<---$ & Religiuosness & .129 & .056 & 2.294 & .022 & \\
\hline Willingness & $<---$ & Income & .382 & .081 & 4.697 & $* * *$ & \\
\hline
\end{tabular}

Source: The primary data was processed in 2016

Table 3: Conclusion of the Hypothesis Testing

\begin{tabular}{lll}
\hline Hypothesis & \multicolumn{1}{l}{ Testing Result } \\
\hline Hypothesis 1 & $\begin{array}{l}\text { The higher the knowledge of the Islam Community in DKI Jakarta, } \\
\text { the higher the willingness to pay zakat. }\end{array}$ & Accepted \\
\hline Hypothesis 2 & $\begin{array}{l}\text { The higher the attitude of the Islam community in DKI Jakarta, the } \\
\text { higher the willingness to pay zakat. }\end{array}$ & Accepted \\
\hline Hypothesis 3 & $\begin{array}{l}\text { The higher the religiousness of the Islam community in DKI Jakarta, } \\
\text { the higher their willingness to pay the zakat }\end{array}$ & Accepted \\
\hline
\end{tabular}




\begin{tabular}{|c|c|c|}
\hline Hypothesis 4 & $\begin{array}{l}\text { The higher the motivation of the Islam community in DKI Jakarta, } \\
\text { the higher the willingness to pay the zakat. }\end{array}$ & Accepted \\
\hline Hypothesis 5 & $\begin{array}{l}\text { The higher the income of the Islam community in DKI Jakarta, the } \\
\text { higher the motivation to pay the zakat. }\end{array}$ & Accepted \\
\hline Hypothesis 6 & $\begin{array}{l}\text { The higher the income of the Islam community in DKI Jakarta, the } \\
\text { higher the willingness to pay the zakat. }\end{array}$ & Accepted \\
\hline
\end{tabular}

5. Conclusion

Source: Results of Analysis and Data Processing, 2016

A Muslim person is required to know the zakat. Sufficient knowledge on the zakat will affect the attitude of the muzakki to pay the zakat in the appropriate manner. Basically, the amanah bestowed by Allah SWT in the form of wealth, is that therein is a portion of other persons that is mandatory be spent/given by a Muslim person. A minimum knowledge of the zakat will result in the inadequate interest to pay the zakat. The higher the knowledge on zakat will enhance the awareness of the muzakki to pay the zakat that in turn will increase the revenue of the zakat. Attitude affects the inclination of a person towards possible outcomes. The more favourable the possible outcome then the stronger the willingness to carry out a certain behaviour, and conversely the less favourable the possible outcome then the weaker the willingness to carry out that certain behaviour. Religiousness pertains to the relations of human being to Allah that is Mighty Powerful, Mighty Compassionatte and Mighty Forgiving that results in the willingness to comply with His Intention and to avert His Prohibitions. Religiousness in Islam is not only realized in the form of ritual dedications but also in the form of other activities. As a holistic system, Islam induces its followers to practice their religious duties in an integral manner. Awareness to implement the zakat has not yet been accompanied by adequate knowldge on the zakat, specifically if compared to the implementation of the other duties such as the sholat and fasting. The inadequate understandiing on the types of wealth that are subject to zakat payment and understanding on the mechanism for paying the zakat in line with with the syarta Islam have resulted in implementation of the zakat duty becoming very dependent on the respespective individuals. Sources of income can be in material forms such as land and can also be in non-materials forms, such as employment or can also be in both forms. Thus inncome is classified into remuneration, salary/wage and profit. Islam obligates that the zakat be paid froim wealth also from income. The level of income can determine the level of zakat paid. The higher the income earned the higher tghe zakat that must be incurred by a Muslim person. A high level of income is expected to increase the willingness to pay the zakat. Generally results of this empirical study have shown that those variables (knowledge, attitude, religiousness, motivation, and income) affect the willingness of the community to pay the zakat. From the hypothesis testing, it is verified that all of the variables positively affect the willingness of the community to pay the zakat. It can be concluded that considering that the majority of the Indonesia populations are Muslims, then the payment of the zakat is an obligation that is contained in the third of the rukun Islam. Thereby stakeholders, including the government must endeavour, through various ways, to optimize payments of the zakat in order to be able to enhance thw welfare of communities specifically in DKI Jakarta and generally in Indonesia. Normatively, religion has created a system for directing the pious behaviour of man. Religious education must be able to meet the basic needs, namely the need for meeting the religious objective for contributing to the goal of realizing a religious life. In this respect, there is a need for understanding the concept of religion in a holistic manner and not merely confined to carrying out the ritual/syariah dimension. The Amil Zakat Institution (LAZ) must more intensively distribute the zakat in the form of productive zakat for community members who want to engage in micro business undertakings, specifically at locations where the muzakki have their residence that subsequently can enhance the awareness of the community on the importance of the LAZ, thereby gradually will enhance confidence in the LAZ.

References

Aaker, D. A., Kumar, V., \& Day, G.S. (2007), Marketing Research 9th ed., John Wiley \& Sons, Inc., US.

Abas, Mohd Yusof (1981), 40 Hadits Pilihan. Kuala Lumpur: Yayasan Dakwah Islamiah Malaysia.

Abu Bakar, Nur Barizah \& Abdul Rashid, Hafiz Majdi (2010), Motivations of Paying Zakat on Income. Evidence from Malaysia. International Journal of Economics and Finance. Vol 2.

Abubakar, Irfan \& Chaider S. Bamualim. (2006), Filantropi Islam dan Keadilan. Sosial, Jakarta: CSRC UIN Syarif Hidayatullah.

Abdul Kadir, Mohd Rizuan. Zainal Abidin, Zulkifli, Anis Ramli, Juliana, Surbaini, Khairul Nizam (2014), Factors Influencing A Business Towards Zakat Payment In Malaysia, International Journal of Science Commerce and Humanities. Vol No. 2.

Abdullah, Al-Muslih \& Shalah, Ash-Shawi (2004), Fikh Ekonomi Keuangan Islam [Penterjemah: Abu Umar Basyir dari "Ma Lā Yasā at-Tājira Jahluhu"], Jakarta: Darul Haq.

Aflah, Kuntarno Noor, dkk. (2006), Zakat \& Peran Negara, Jakarta: Forum Zakat al-Utsaimin.

Agustianto (2002), Percikan Pemikiran Ekonomi Islam. Jakarta: Forum Kajian Ekonomi dan Perbankan Islam (FKEI) bekerja sama dengan Cita Pustaka Media. 
Ahmadi, Abu (2009), Psikologi Sosial, Jakarta: PT. Rieneke Cipta.

Arbuckle, J.L. and Wothke, W.(1999), AMOS users guide version 4.0., Chicago IL: Small Water.

Ajzen, I. (2005), Attitudes, Personality and Behavior, $2^{\text {nd }}$ Edition, McGraw-Hill Professional Publishing, Berkshire, GBR.

Ajzen, Icek and Fishbein (1980), Theory of Reasoned Action, Edisi Kesatu [Penterjemah: Jogiyanto], Yogyakarta: Andi Publisher.

Ajzen, Icek and Driver, B.L. (2002), Prediction of Leisure Participation from Behavioral, Normative and Control Beliefs: An Application of Theory of Planned Behavior, Leisure Sciences, Vol. 13, 185-204.

Ajzen, Fishbein, I, Belief (2005), Attitude, Intention and Behavior, An Introduction to Theory and Research, London: Addison-Wesley Publishing Comp.

Azman, Farah Mastura Noor \& Bidin, Zainol (2015), Factors Influencing Zakat. Compliance Behavior on Saving, Kuala Lumpur: International Journal of Business and Social.

Al Munawir, Ahmad Warson (1997), Kamus Arab Indonesia Al Munawir, Surabaya: Pustaka Progressif.

Al-Ghazali, Imam (1990), Ihya' Ulumuddin, [Penterjemah: Muhammad Zuhri] Jilid I, Semarang: Asy-Syifa.

Al-Zuhayli, Wahbah (2008), Zakat Kajian Berbagai Mazhab, [Penterjemah: Agus Efendi \& Baharuddin Fananny], Bandung: PT Remaja Rosda Karya.

Alam, Syed Shah. Janor, Hawati. Zanariah. Wel Che Aniza Che. Ahsan, Nilufar. (2012), Is Religiosity an Important Factor in Influencing the Intention to Undertake Islamic Home Financing in Klang Valley?, World Applied Sciences Journal 19 (7): 1030-1041.

Ali, Mohamad Daud \& Habibah Daud (1995), Lembaga-lembaga Islam di Indonesia, Jakarta: Raja Grafindo Persada.

Ali, Nuruddin Mhd (2006), Zakat Sebagai Instrumen Dalam Kebijakan Fiskal, Jakarta: PT Raja Grafindo Persada.

Ancok, Djamaludin \& Suroso, Fuat Nashori. (2005), Psikologi Islam Solusi Islam Atas Problem-Problem Psikologi, Yogyakarta: Pustaka Pelajar.

Arikunto Suharsimi (2010), Prosedur Penelitian: Suatu Pendekatan Praktek. Jakarta: Rineka Cipta.

Azizi, Hikayah Nur Farida (2008), Variabel-Variabel Yang Mempengaruhi Pembayaran Zakat Oleh Para Muzakki: Studi Kasus Pengelola Lembaga Keuangan Syariah di Kota Yogyakarta, Yogyakarta: Fakultas Ekonomi, Universitas Gadjah Mada.

Azman, Farah Mastura Noor \& Bidin, Zainol (2015), Factors Influencing Zakat Compliance Behavior and Saving, Internation Journal of Business and Social Research. Vol 05.

Baumgartner, H \& Homburg, C. (1996), Applications of Structural Equation Modeling in Marketing and Consumer Research: A review, International Journal of Research in Marketing, (13),139-161.

Bentler, P. (1983), Some New Covariance Stucture Model, Testing Structural. Equation Model, New Delhi: Sage Publications.

Bobek, Donna D., Richard C. Hatfield (2003), An Investigation of the Theory of Planned Behavior and The Role of Moral Obligation in Tax Compliance, Behavioral Research in Accounting, Vol. 15.

Brahmasari, I. \& Suprayitno, A. (2008), Pengaruh Motivasi Kerja, Kepemimpinan dan Budaya Organisasi Terhadap Kepuasan Kerja Karyawan serta Dampaknya pada Kinerja Perusahaan (Studi kasus pada PT. Pei Hai International Wiratama Indonesia). Jurnal Manajemen dan Kewirausahaan, Vol 10, No 2, September 2008.

Choudhury, M.A. (1999), Comparative Economic Theory - Occidental and Islamic Perpsectives, Klewer Academic, Choudhury, M. A \& Zaman, S. I. A Theory Of Ethical Endogeneity In Socioeconomic Development: A Mathematical Exploration.

Choudhury, M.A. \& G. Korvin, (2001), Knowledge-Induced Socio-Scientific Systems, International Journal of Sustainability in Higher Education, Vol. 3, No.1.

Choudhury, M.A (2004), Explaining the Qur'an, a Socio-Scientific Inquiry, Lewiston, New York: The Edwin Mellen Press.

Choudhury, M.A. (2005), Learning Systems, Kybernetes: International Journal of Systems and Cybernetics, 33:1.

Choudhury, M.A. (2005), "Learning Systems”, Kybernetes: International Journal of Systems and Cybernetics, $33: 1$.

Choudhury, M.A. and Zaman, S. I., (2006) forthcoming. Learning Sets and Topologies, Kybernetes: International Journal of Systems and Cybernetics, 35: 3-7.

Choudhury, M.A. and Hossain, M.S, (2006), forthcoming. Evolutionary Epistemology and Development Planning, Lewiston, New York: The Edwin Mellen Press.

Choudhury, M.A (2006a) forthcoming. Science And Epistemology In The Qur'an 5: The Qur'anic Principle of Complementarities Applied to Social and Scientific Themes, Lewiston, New York: The Edwin Mellen Press. 
Choudhury, M.A. (2006b). Generic title, Science and Epistemology in the Qur'an, 5 volumes, Lewiston, New York: The Edwin Mellen Press.

Choudhury, M.A. (2006c) forthcoming. Islamic Economics and Finance: Where Do They Stand?, Proceedings of the Sixth International Conference on IsEconomics, Finance and Banking, Jeddah, Saudi Arabia: Islamic Development Bank.

Choudhury, M.A. (2011), A Probabilistic Model of Learning Fields, The Journal of Muamalat and Islamic Finance Research, (7:1).

Cooper, R. Donald \& Emory, William C. (1996), Metode Penelitian Bisnis, Jakarta: Erlangga.

Cooper, D. \& Schindler, P. S. (2008), Marketing Research, McGraw Hill Companies Inc., New York.

Djarwanto (2003), Statistik Non Parametrik, Yogyakarta : BPFE - Yogyakarta.

Djuanda, Gustian dkk. (2010), Pelaporan Zakat Pengurang Pajak Penghasilan, Jakarta: Raja Grafindo Persada.

Engel, J. F., Blackwell, R. D. \& Miniard, P.W. (2001), Perilaku Konsumen Jilid 2, Edisi Keenam, Jakarta : Penerbit Binarupa Aksara.

Ferdinand, Augusty (2006), Metode Penelitian Manajemen, Semarang: Badan Penerbit Universitas Diponegoro.

Ghozali, Imam (2008), Aplikasi Analisis Multivariate dengan Program SPSS Cetakan IV, Semarang: Badan Penerbit Universitas Diponegoro.

Gibson, J. L, Ivancevich, J. M \& Donnelly, J. H. (1987), Teori dan Perilaku Organisasi, Jurnal Manajemen Kinerja dan Kewirausahaan, Vol 6, No.1, Januari 2011.

Gujarati \& Porter (2009), Dasar-Dasar Ekonometrika, Jakarta: Salemba Empat.

Hafidhuddin, Didin (2002), Zakat Dalam Perekonomian Modern, Jakarta: Gema Insani.

Hair, Joseph F. et al. (2006), Multivariate Data Analysis. Fifth Edition, Jakarta: Gramedia, Pustaka Utama.

Hakim, Budi Rahmat, Abdul Gafur \& Rohana Faridah (2014), Studi Manajemen Kelembagaan Amil Zakat di Kalimantan Selatan, Jurnal Tashwir Vol. 2 No. 3, Januari - Juni 2014.

Handoko, Hani (2002), Manajemen Personalia dan Sumber Daya Manusia (Edisi 2), Yogyakarta: BPFE.

Hermawan, Rachman \& Zulfikar Zen (2006), Etika Kepustakawanan: Suatu Pendekatan Terhadap Kode Etik Pustakawan Indonesia, Jakarta: Sagung Seto.

Huda, Nurul \& Ririn, Nova. Mardhoni, Yosi \& Putra, Purnama (2012), The Analysis of Attitudes, Subjective Norms, and Behavioral Control on Muzakki's Intention to Pay Zakah, International Journal of Business and Social Science Vol. 3.

Indriantoro, Nur \& Bambang Supomo (2002), Metodologi Penelitian Bisnis. Yogyakarta: BPFE Yogyakarta.

Jalaludin (2012), Pengaruh Zakat, Infaq dan Shodaqoh Produktif Terhadap Pertumbuhan Usaha Mikro dan Penyerapan Tenaga Kerja Serte Kesejahteraan Mustahik. Majalah Ekonomi Tahun XX11. Vol 3.

Kadariah (2001), Evaluasi Proyek: Analisis Ekonomis, Jakarta: Lembaga Penerbitan Fakultas Ekonomi Universitas Indonesia.

Kahmad, Dadang (2009), Sosiologi Agama, Bandung: PT. Remaja Rosda Karya.

Kamil, MD. Idris (2002), Peranan Sikap Dalam Gelagat Kepatuhan Zakat Pendapatan Gaji, Universiti Utara Malaysia: Jurnal Analisis 9 (1\&2).

Kanji, Lusiana, Habbe, H. Abd. Hamid \& Mediaty (2011), Determinant Factors Motivation Paying Zakat Zakat and Magnitude of Value.

Karim, Adiwarman Aswar (2001), Ekonomi Islam Suatu kajian Kontemporer, Jakarta: Gema Insani Press.

Koesmono, T. (2005), Pengaruh Budaya Organisasi Terhadap Motivasi dan Kepuasan Kerja Serta Kinerja Karyawan Pada Sub Sektor Industri Pengolahan Kayu Skala Menengah di Jawa Timur, Jurnal Manajemen dan Kewirausahaan, Vol.7 No.2.

Kotler, Philip (2005), Manajemen Pemasaran, Jilid 1 dan 2, Jakarta: PT. Indeks Kelompok Gramedia.

Kumpulan Fatwa Ibnu Taimiyah, Jilid 25.

Kuncoro, Achmad \& Riduan, Engkos (2008), Cara menggunakan dan memaknai Analisis Jalur, Bandung: Alfabeta.

Kurniawati (2005), Muslim Philanthropy: Potential and Reality of Zakat in Indonesia, Jakarta: Survey Results in Ten Cities".

Laela, Sugiyarti Fatma (2010). Analisis Faktor-Faktor Yang Mempengaruhi Kinerja Organisasi Pengelola Zakat. Islamic and Business Review Vol 5 No. 2.

Lau, A.S.M. (2002), Strategies to Motivate Brokers Adopting On-line Trading in Hong Kong Financial Market, Review of Pacific Basin Financial Markets and Policies.

Majid, M Nazori (2003), Pemikiran Ekonomi Islam Abu Yusuf: Relevansi Dengan Ekonomi Kekinian, Yogyakarta: Pusat Studi Ekonomi Islam - STIS.

Maman (2006), Metodologi Penelitian Agama: Teori dan Praktik, Jakarta: Raja Grafindo Persada.

Mannan, M. Abdul (1997), Teori dan Praktik Ekonomi Islam [Penterjemah: M. Nastangin dari "Islamic Economics Theory And Practice"], Yogyakarta: Dana Bakti Primayasa.

Marihot, Tua Efendi \& Hariandja, (2005), Manajemen Sumber Daya Manusia, Jakarta: PT.Grasindo 
Mas'udi, Masdar F. (1991), Agama Keadilan Risalah Zakat (Pajak dalam Islam), Jakarta: Pustaka Firdaus, hlm.105.

Mohdali, Raihana. (2011), The Influence of Religiosity on Taxpayers' Compliance Attitudes, Empirical Evidence from a Mixed-Methods Study.

Mohammad, Hidayat (2010), An Introduction to The Syaria Economic, Jakarta: PT. Bestari Buana Murni.

Muflih, Muhammad (2006), Perilaku Konsumen dalam Perspektif Ilmu Ekonomi. Islam, Jakarta: PT Raja Grafindo Persada.

Mufraini, M. Arif (2006), Akuntansi dan Manajemen Zakat: Mengkomunikasikan Kesadaran dan Membangun Jaringan, edisi pertama, Jakarta: Kencana Prenada Media Group.

Muhammad (2002), Kebijakan Fiskal dan Moneter Dalam Ekonomi Islam, Jakarta: Salemba Empat.

Muhammad (2002), Zakat Profesi Wacana Pemikiran Dalam Fiqih Kontemporer, Jakarta: Salemba Diniyah.

Muhammad (2010), Bank Syariah: Analisis Kekuatan, Kelemahan, Peluang, dan Ancaman, Yogyakarta: Ekonisia.

Muhammad, Hadi (2010), Problematika Zakat Profesi dan Solusinya, Tinjauan Sosiologi Hukum Islam, Yogyakarta: Pustaka Pelajar.

Mukarromah, Oom, Badrudin (2013), Politik Ekonomi Syariah, Jakarta: PT Raja Grafindo Persada.

Mursyidi (2003), Akuntansi Zakat Kontemporer, Bandung: Remaja Kosda Karya.

Mus'ab, A. (2011), Pengaruh Religiositas, Tingkat Penghasilan, dan Layanan Terhadap Minat Muzakki Untuk Membayar Zakat Maal di LAZIS NU, Yogyakarta: UIN Sunan Kalijaga Yogyakarta.

Muthohar, Ahmad Mifdlol (2012), Analisis Pengaruh Religiusitas, Keyakinan Berkah dan Pelayanan Lembaga Zakat Terhadap Pilihan Pembayaran Zakat di Lembaga Zakat.

Nawawi, Imam (2006), Mukhtashor Riyadhus Sholihin, Bandung: Irsyad Baitus Salam.

Notoatmodjo, Soekidjo (2010), Metode Penelitian Kesehatan, Jakarta: Rineka Cipta.

Oskamp, S. \& Schultz, P. W. (2005), Attitudes and Opinions, Mahwah, NJ: Lawrence Erlbaum Associates.

Purnama, Tata Septayuda (2011), Hubungan Aspek Religiusitas dan Aspek Dukungan Sosial terhadap Konsep Diri Selebriti di Kelompok PengajianOrbit Jakarta, Jakarta: Universitas Indonesia.

Pusat Bahasa (2008), Kamus Besar Bahasa Indonesia,. Jakarta: PT Gramedia Pustaka Utama.

Qardhawi, Yusuf (1993), “Al-Ibadah Fil-Islam”, Beirut: Muassasah Risalah.

Qardhawi, Yusuf (2004), Fiqh Zakat, Semarang: Kurnia Esa.

Qardhawi, Yusuf (2005), Spektrum Zakat: Dalam Membangun Ekonomi Kerakyatan, Jakarta: Zikrul Hakim.

Qardhawi, Yusuf (2009), Kiat Islam Mengentaskan Kemiskinan, Jakarta: Gema Insani Pers.

Qardhawi, Yusuf (2010), Hukum Zakat, [Penterjemah: Salman Harun, Didin Hafidhudin, Hasanudin], Bogor: Lintera Antara Nusa.

Qodir, Zuly, (2005), Agama dan Mitos Dagang, Solo: Pondok Edukasi.

Razak, Nasrudin (1989), Dienul Islam: Penafsiran Kembali Islam Sebagai Suatu Aqidah dan Way of Life, Bandung: Al-Maarif.

Rhodes, R.E and Courneya,K.S. (2003), Modelling the Theory of Planned Behavior and Past Behavior, Psychology, Health and Medicine, Vol. 8, No.1.

Ridwan, Syamsuri (2004), Zakat di dalam Islam, Jakarta: Pradnya Paramita.

Robbins, Stephen P. Benyamin Molan (2006), Perilaku Organisasi Jilid 1. Jakarta: PT Indeks, Gramedia Group.

Rofiq, Ahmad (2004), Fiqih Kontekstual dari Normatif ke Pemaknaan Sosial, Semarang: Kerjasama Pustaka Pelajar Yogyakarta dan LSM Damar.

Rouf, Abdul (2011), Analisis Faktor yang Mempengaruhi Minat Masyarakat Membayar Zakat melalui Rumah Zakat Cabang Semarang, Semarang: Fakultas Syariah IAIN Walisongo Semarang.

Saad, Ram Al Jaffri. Bidin, Zainol. Idris, Kamil Md. \& Hussain, Hairi Md. (2010), Factors that Influenced the Business Zakah Compliance Behaviour.

Sabiq, Sayyid (1990), Fikih Sunnah, [Penterjemah: Mahyudin Syaf], Bandung: PT. Al-Ma'arif.

Saefuddin, Ahmad Muflih (1998), Filsafat Nilai Dasar, Nilai Instrumental dan Fungsionalisasi Konsep Ekonomi Islam, dalam Sasono dkk, Solusi Islam atas Problematika Umat, Jakarta: Gema Insani Press.

Salamulloh, M.Alaika (2008), Akhlak Hubungan Horizontal, Yogyakarta:Pustaka.

Samuelson, Paul A \& Nordhaus, William D. (2005), Ilmu Makro Ekonomi, Jakarta: Salemba.

Sapingi, Raedah. Ahmad, Noormala \& Mohamad, Marziana (2011), A Study on Zakah of Employment Income: Factors That Influence Academics Intention to Pay Zakah. International Conference on Business Economic Research.

Sherif, Muzafer and C. Hovland (1966), Social Judgment, London: Yale University Press, New Haven.

Shimp, T.A. and A. Kavas (1984), The Theory of Reasoned Action Applied to Coupon, Journal of Consumer Research

Sholahuddin, M. (2006), Baitul Maal Berstandar Mata Uang Syariah, Makalah Ikatan Ahli Ekonomi Indonesia, Proceedings of International Seminar On Islamic Economics As A Solution, Medan, 18-19 September. 
Silalahi, Ulber (2006), Metode Penelitian Sosial, Bandung: Unpar Press.

Silver. Hmelo, C. E. \& Barrows, H. S. (2006), Goals and Strategies of a Problem Based Learning Facilitator. The Interdisciplinary Journal of Problem-Based Learning , 1, (1), 21-39

Simamora, H. (2006), Manajemen Sumber Daya Manusia, Yogyakarta: STIE YKPN.

Singarimbun, Masri dkk. (1985), Metode Penelitian Survei, Jakarta: LP3ES.

Stoner, James A.F.(2006), Management. Englewood Cliffs, NJ.:Prentice Hall, Inc.

Sugiyono (2006), Metode Penelitian Pendidikan, Pendekatan Kuantitatif, Kualitatif dan R\&D. Bandung: Alfabeta.

Suhardiyanto (2001), Pendidikan Religiusitas, Yogyakarta: Kanisius.

Sukirno, Sadono (2005), Pengantar Makro Ekonomi, Jakarta: PT. Raja Grafindo Persada.

Sumanta, Jaka (2005), Fenomena Lingkaran Kemiskinan: Analisis Ekonometrika Regional, Jurnal Kebijakan Ekonomi, Vol 1, no 2.

Sunuharyo, Bambang (1982), Pendapatan dan Pengeluaran Rumah Tangga Pegawai Golongan Rendah di Perumnas Klender [dalam Mulyanto Sumardi dan Han Dieter-Evers, Kemiskinan dan Kebutuhan Pokok], Jakarta: Rajawali Press.

Suprayogi, Agus (2011), Faktor-Faktor Yang Mempengaruhi Keinginan dan Preferensi Pengusaha Mikro Untuk Berzakat, Depok: Universitas Indonesia.

Tanaka JS, Huba GJ. (1989), A Fit Index for Covariance tructure Model under. Arbritary GLS Estimators, British Jurnal of Mathematical dan Statistical. Psychology 38:197-201.

Taylor, S. \& P. A. Todd (1995), Understanding Information Technology Usage: A Test of Competing Models, Information System Research 6.

Thomas, W.I. \& Znaniecki, F. (2010), The Polish Peasant in Europe and America, Monograph of an Immigrant Group.

Tisniwati, Baiq (2012), Analisis Faktor-Faktor yang Mempengaruhi Tingkat Kemiskinan di Indonesia, Jurnal Ekonomi Pembangunan Vol.10 No.1.

Turner, Brian S., Agama (2006), Teori Sosial Rangka - Pikir Sosiologi Dalam Membaca Eksistensi Tuhan Diantara Gelegar Ideologi-ideologi Kontemporer, Yogyakarta: IRCiSoD, Cet. II.

Uma Sekaran (2007), Research Methods For Business, Jakarta: Salemba Empat.

Walgito, Bimo (2010), Psikologi Sosial Suatu Pengantar, Yogyakarta: Andi Yogyakarta.

Wibisono. Dermawan (2005), Riset Bisnis: Panduan Bagi Praktisi dan Akademisi, Jakarta: PT Gramedia Pustaka Utama.

Yafie, KH Ali (1994), Menggagas Fiqih Sosial, Bandung: Mizan.

Young, Kimbal (2007), Sociology and Social Life, New York: American Book Company.

Zayadi, Ahmad (2009), Zakat Dalam Ekonomi Masyarakat, Suara Pembaruan.

Zikmund, William G, (2007), Customer Relationship Management: Integrating Marketing Strategy and Information Technology, New Jersey: John Wiley and Sons.

Zulfahmi, Bustami. (2007), Implikasi Positifikasi Hukum Zakat Dalam Pemberdayaan Ekonomi Kerakyatan, Hukum Islam, Vol. VIII, No. 6.

Departemen Agama RI., Al-Qur'an dan Terjemahannya, CV. Asy Syifa', Semarang, 1999. Al-Qur'an dalam surat At-Taubah: 103.

Indonesia Magnificence Zakat/IMZ (2011).” Hasil Riset”.

\section{Copyrights}

Copyright for this article is retained by the author(s), with first publication rights granted to the journal.

This is an open-access article distributed under the terms and conditions of the Creative Commons Attribution license (http://creativecommons.org/licenses/by/4.0/) 